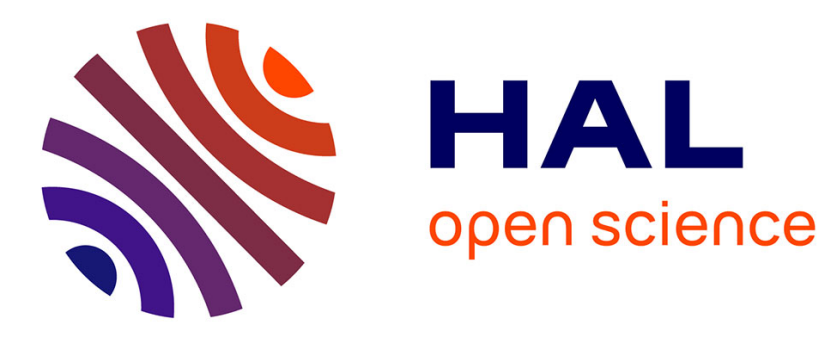

\title{
Bacterial accumulation by (Annelida: Polychaeta): A tool for biomonitoring marine systems and restoring polluted waters
}

Margherita Licciano, Loredana Stabili, Adriana Giangrande, Rosa Anna Cavallo

\section{To cite this version:}

Margherita Licciano, Loredana Stabili, Adriana Giangrande, Rosa Anna Cavallo. Bacterial accumulation by (Annelida: Polychaeta): A tool for biomonitoring marine systems and restoring polluted waters. Marine Environmental Research, 2007, 63 (3), pp.291. 10.1016/j.marenvres.2006.11.003 . hal-00501895

\section{HAL Id: hal-00501895 https://hal.science/hal-00501895}

Submitted on 13 Jul 2010

HAL is a multi-disciplinary open access archive for the deposit and dissemination of scientific research documents, whether they are published or not. The documents may come from teaching and research institutions in France or abroad, or from public or private research centers.
L'archive ouverte pluridisciplinaire HAL, est destinée au dépôt et à la diffusion de documents scientifiques de niveau recherche, publiés ou non, émanant des établissements d'enseignement et de recherche français ou étrangers, des laboratoires publics ou privés. 


\section{Accepted Manuscript}

Bacterial accumulation by Branchiomma luctuosum (Annelida: Polychaeta): A tool for biomonitoring marine systems and restoring polluted waters

Margherita Licciano, Loredana Stabili, Adriana Giangrande, Rosa Anna Cavallo

PII:

S0141-1136(06)00208-X

DOI:

10.1016/j.marenvres.2006.11.003

Reference:

MERE 3079

To appear in:

Marine Environmental Research

Received Date: $\quad 16$ February 2006

Revised Date: $\quad 16$ November 2006

Accepted Date: $\quad 21$ November 2006

Please cite this article as: Licciano, M., Stabili, L., Giangrande, A., Cavallo, R.A., Bacterial accumulation by Branchiomma luctuosum (Annelida: Polychaeta): A tool for biomonitoring marine systems and restoring polluted waters, Marine Environmental Research (2006), doi: 10.1016/j.marenvres.2006.11.003

This is a PDF file of an unedited manuscript that has been accepted for publication. As a service to our customers we are providing this early version of the manuscript. The manuscript will undergo copyediting, typesetting, and review of the resulting proof before it is published in its final form. Please note that during the production process errors may be discovered which could affect the content, and all legal disclaimers that apply to the journal pertain. 
Bacterial accumulation by Branchiomma luctuosum (Annelida: Polychaeta): a tool for biomonitoring marine systems and restoring polluted waters

Margherita Licciano $^{1 *}$, Loredana Stabili ${ }^{2}$, Adriana Giangrande ${ }^{1}$, Rosa Anna Cavallo ${ }^{2}$

${ }^{1}$ Dipartimento di Scienze e Tecnologie Biologiche ed Ambientali, Via Prov. LecceMonteroni, 73100-Lecce, Italy

${ }^{2}$ Istituto per l'Ambiente Marino Costiero - Sezione di Taranto - CNR, Via Roma 3, 74100-Taranto, Italy

*Corresponding author. Tel.: +39 0832 298897; fax: +39 0832298626

E-mail address: margherita.licciano@unile.it 


\begin{abstract}
In this study, we examined the bacterial accumulation in the filter feeder polychaete Branchiomma luctuosum GRUBE (Sabellidae). Analyses were performed on worm homogenates from 'unstarved' and 'starved' individuals, and seawater from the same sampling site (Gulf of Taranto, Western Mediterranean, Italy). Densities of culturable heterotrophic bacteria $\left(22^{\circ} \mathrm{C}\right)$, total culturable bacteria at $37^{\circ} \mathrm{C}$ and halophilic vibrios at 22 and $35^{\circ} \mathrm{C}$ were measured on Marine Agar 2216, Plate Count Agar and thiosulphatecitrate-bile-salt-agar (TCBS) plus $2 \% \mathrm{NaCl}$, respectively. Total and faecal coliforms as well as faecal streptococci were determined by the Most Probable Number method. Results showed that B. luctuosum is able to accumulate all the considered six microbiological groups with a higher efficiency for autochthonous bacteria. The analysis also indicated that bacterial groups differ in their resistance to digestion by B. luctuosum. Our data suggest the potential of B. luctuosum as an useful bioindicator to assess low levels of microbiological water pollution as well as bioremediator of microbial polluted waters.
\end{abstract}

Keywords: Bacterial accumulation; Bioindicator; Bioremediation; Branchiomma luctuosum; Faecal contamination indicators; Filter feeding; Polychaetes; Vibrio 


\section{Introduction}

Filter-feeding is a trophic strategy widely represented among benthic marine invertebrates and plays a crucial role in energy transfer processes in marine systems for the pelagic and benthic coupling (Cloern, 1982; Officer et al., 1982; Kimmerer et al., 1994; Gili \& Coma, 1998; Widdows et al., 1998; Widdows et al., 2000; Widdows et al., 2004).

Polychaetes are one of the best represented taxa of marine invertebrates in benthic assemblages and in various groups are able to collect particles suspended in the water column. Species belonging to the family Sabellidae are easily recognizable for the presence of an elaborated tentacular crown that expands out of the tube they inhabit. A number of studies on Sabellidae has provided descriptions of filtering organs and particle capture mechanisms (Wells, 1952; Fitzsimons, 1965; Lewis, 1968; Bonar, 1972) but there are very few accounts of the qualitative and quantitative aspects of the filtration process (Dales, 1957; Shumway et al., 1988; Riisgård \& Ivarsson, 1990; Clapin, 1996; Licciano et al., 2005; Stabili et al., 2006). Sabellids are able to sort collected material of different sizes: small particles are swallowed, while large ones are pushed away from the mouth and ejected into the water.

As a consequence of the filter feeding activity, sabellids may accumulate and concentrate many pollutants in seawater, particularly those which are particulate or associated with particles (Cavallo \& Giangrande, 2002; Bocchetti et al., 2004; Fattorini et al., 2005). This ability to accumulate materials may facilitate the detection and measurement of pollutants at very low environmental concentration. The use of bioindicators for monitoring water quality, in fact, is essentially based on the filter-feeders' ability to accumulate contaminants in their tissues to a degree proportional to their bioavailability (Widdows \& Donkin, 1992; Andral et al., 2004). 
Field and laboratory studies on filter feeder polychaetes have been performed employing phytoplankton as a feeding source (Shumway et al., 1988; Clapin, 1996), even though the nature of suspended matter may be either non-living (detrital organic carbon) or living (bacteria, phytoplankton and zooplankton) (Jørgensen, 1966, 1975; Wotton, 1994; Riisgård \& Larsen, 1995, 2001a, 2001b; Silverman et al., 1995, 1997; Gili \& Coma, 1998). Many studies dealing with different benthic filter feeder organisms feeding on marine and terrestrial bacteria have been carried out (Jørgensen et al., 1984; Prieur et al., 1990; Bak et al., 1998; Ribes et al., 1999). Special attention was paid to molluscs, particularly bivalves. The potential of bivalves in microbiological surveys has been intensively investigated in relation to their capability to concentrate particles, bacteria and viruses and also in relation to potential human health risks related to their physiology, production and consumption (Wood, 1957; Ayres et al., 1978; Bostock, 1979; Bolinches et al., 1986; Prieur et al., 1990; Yam et al., 1999). Quantitative data on sabellid filtration of bacterioplankton are very scant and limited to Sabella spallanzanii (Licciano et al., 2003; Stabili et al., 2006), with the exception of one paper dealing with the clearance rate of Branchiomma luctuosum on a pure culture of Vibrio alginolyticus (Licciano et al., 2005).

The present study is focused on the filter-feeder sabellid Branchiomma luctuosum GRUBE, which forms dense populations on hard substrata in heavy eutrophic sheltered marine areas of the Mediterranean basin (Licciano et al., 2002). The species is a lessepsian migrant (from the Red Sea) recorded in the Mediterranean since 1983 (Bianchi, 1983; Knight-Jones \& Ergen, 1991). The aim of this work is to provide evidence for its ability to filter and consequently concentrate several bacterial groups, and to assess if this species may substantially contribute to the removal of bacteria from the water column by its 
potential accumulation capability thus constituting a potential candidate for bioremediation of microbial polluted waters.

\section{Materials and methods}

\subsection{Samples collection}

Adult specimens of B. luctuosum were collected along a dock wall by SCUBA divers in the Gulf of Taranto (Ionian Sea, Italy). Water samples were collected from the same sampling site with 51 sterilized Niskin bottles and processed within $4 \mathrm{~h}$ of sampling to enumerate bacteria. Immediately upon return to the laboratory, worms were cleaned of any tube epibionts and randomly divided into two sets. Specimens from one set (90 individuals) were separated in 9 groups each consisting of 10 individuals and immediately extracted from the tubes and utilized for the analysis ('unstarved' condition). The second set (90 individuals) was divided and placed in 9 aquaria each containing 10 individuals. Each aquarium was filled with filtered $(0.22 \mu \mathrm{m}$ pore size filters, Millipore) seawater and acclimatized in a temperature controlled room $\left(22^{\circ} \mathrm{C}\right)$ for $48 \mathrm{~h}$ to ensure the reduction of pre-existing microorganisms before the beginning of the experiment ('starved' condition).

\subsection{Bacteriological analyses}

The bacteriological analyses were performed on seawater from the worm sampling site and on both starved and unstarved worms. Each group of 10 worms ( 9 groups of starved and 9 of unstarved worms) was processed separately for the enumeration of bacteria. After their extraction from the tubes and washing several times with sterile seawater, worms were homogenized for $90 \mathrm{~s}$ in a Waring blender. The homogenates (ca. $100 \mathrm{~g}$ ) were filtered through sterile gauze and diluted with filtered $(0.22 \mu \mathrm{m})$ seawater to obtain a 1:10 (w/v) dilution. 
Quantitative analyses of culturable heterotrophic bacteria $\left(22^{\circ} \mathrm{C}\right)$, total culturable bacteria at $37^{\circ} \mathrm{C}$, culturable halophilic vibrios at 22 and $35^{\circ} \mathrm{C}$, faecal and total coliforms as well as faecal streptococci were performed on seawater and on worm homogenates.

To enumerate the culturable halophilic vibrios in seawater, 1, 5 and $10 \mathrm{ml}$ were filtered on $0.45 \mu \mathrm{m}$ pore size filters that were aseptically placed onto thiosulphate-citrate-bile-saltagar (TCBS) plus $2 \% \mathrm{NaCl}$. After incubation for $48 \mathrm{~h}$ at 22 and $35^{\circ} \mathrm{C}$, the colonies grown were counted in terms of colony forming units (CFU). For the enumeration of vibrios in polychaetes, $0.1 \mathrm{ml}$ of each worm homogenate and of appropriate decimal dilutions were plated on TCBS agar and after incubation of $48 \mathrm{~h}$ at 22 and $35^{\circ} \mathrm{C}$, the culturable vibrios developed on each plate were counted.

Results were referred as mean value recorded at 22 and $35^{\circ} \mathrm{C}$.

Final bacterial concentrations were obtained taking into account the dilution factors.

Total and faecal coliforms as well as faecal streptococci were determined by the Most Probable Number (MPN) method using the standard five-tube method of ten-fold dilutions for seawater samples and three-tube MPN series for worm homogenates (APHA, AWWA, WEF, 1998). For total and faecal coliforms determination, lactose broth and brilliant-green-lactose broth were used as cultural media in the presumptive and confirmative test, respectively. For faecal streptococci the presumptive test was performed using Azide broth and the confirmative one using Ethyl violet azide broth. Results were referred as MPN $100 \mathrm{ml}^{-1}$ or $100 \mathrm{~g}^{-1}$, for water and worm samples, respectively.

Culturable heterotrophic bacteria abundance was determined by spreading $100 \mu \mathrm{l}$ of undiluted sea water or worm homogenates and the respective serial dilutions in triplicate on plates of Marine agar 2216 (Difco, USA). The plates were incubated at $22^{\circ} \mathrm{C}$ over 7 days, then the colonies were counted. 
Total culturable bacterial densities growing at $37^{\circ} \mathrm{C}$, indicating the fraction of bacterial potentially pathogenic to humans, were determined as previously described for the heterotrophic bacteria but using Plate Count Agar (PCA) as the culture medium.

\subsection{Statistical analysis}

The experimental design consisted of two factors: Concentration $(\mathrm{Co})$, with two levels (i. e. seawater and polychaetes, fixed) and Time (Ti), with two levels (i. e. before and after worm starvation, fixed and orthogonal to Concentration). Analysis of variance (ANOVA) was used to assess differences in the mean abundance of the bacteriological groups between seawater and worms before $\left(\mathrm{Ti}_{0}\right)$ and after $\left(\mathrm{Ti}_{1}\right)$ worm starvation. Prior to analysis, the homogeneity of variance was tested using Cochran's test and, if necessary, data were $\ln (\mathrm{x}+1)$ transformed to remove heterostochasticity. The Student-NewmanKeuls test (SNK) was used for post-hoc comparisons among means (Underwood, 1997). The analysis was done using GMAV 5 computer program (University of Sidney, Australia).

\section{Results}

Culturable heterotrophic bacteria $\left(22^{\circ} \mathrm{C}\right)$ densities (Fig. 1a) found in B. luctuosum_differed from those found in the surrounding seawater $\left(8.8 \pm 1.5 \times 10^{4} \mathrm{CFU} \mathrm{g}^{-1}\right.$ and $3.1 \pm 0.2 \times 10^{3}$ $\mathrm{CFU} \mathrm{ml} \mathrm{m}^{-1}$ respectively). Starved individuals concentrated this kind of bacteria of about 1 order of magnitude $\left(9.6 \pm 1.2 \times 10^{5} \mathrm{CFU} \mathrm{g}^{-1}\right)$ with respect to the values detected in unstarved animals.

Analysis of variance performed on the abundance of this bacterial group in worm homogenate and seawater samples revealed a significant Co $x$ Ti interaction $(P<0.001)$ (Table 1). Post-hoc comparisons suggested that heterotrophic bacterial density was 
significantly lower in unstarved than in starved worms $(P<0.01)$ and that the bacterial concentrations did not vary significantly in seawater samples over time.

Figure $1 \mathrm{~b}$ reports the densities of halophilic vibrios growing at 22 and $35^{\circ} \mathrm{C}$ detected in $B$. luctuosum homogenates and the surrounding seawater. Starved animals showed the highest vibrios densities with a mean value of $2.4 \pm 0.4 \times 10^{5} \mathrm{CFU} \mathrm{g}{ }^{-1}$. Analysis of variance (Table 1) revealed a significant Co $x$ Ti interaction at $P<0.001$. Bacteria were significantly more concentrated in unstarved and starved polychaetes in comparison to the seawater, as established by SNK test $(P<0.01)$. Halophilic vibrios concentrations in unstarved animals were significantly lower than starved ones $(P<0.01)$ whilst no significant differences in vibrios abundance were evidenced in seawater samples at $\mathrm{Ti}_{0}$ and $\mathrm{Ti}_{1}$.

The abundance of total culturable bacteria at $37^{\circ} \mathrm{C}\left(\right.$ about $1.8 \times 10^{4} \mathrm{CFU} \mathrm{g}{ }^{-1}$ ) did not differ significantly in starved and unstarved B. luctuosum (Table 1, Fig. 1c) whereas the bacterial concentration measured at $\mathrm{Ti}_{0}$ and $\mathrm{Ti}_{1}$ in polychaetes was significantly higher $(P$ $<0.001$ ) than the sampling site seawater where the density was $7.4 \pm 1.3 \times 10^{2} \mathrm{CFU} \mathrm{ml}^{-1}$.

To evaluate the accumulation capability of B. luctuosum with respect to the classical microbial pollution indicators, we analyzed the densities of total and faecal coliforms as well as faecal streptococci.

Total and faecal coliforms concentration trends were similar (Fig. 2a) and in both cases bacterial densities were about 5 times lower in the unstarved worms than in the surrounding environment. Particularly, total coliform were $40 \pm 4$ MPN $100 \mathrm{~g}^{-1}$ in the worms and $131 \pm 18.5 \mathrm{MPN} 100 \mathrm{ml}^{-1}$ in the seawater. Faecal coliform concentrations were $40 \pm 4 \mathrm{MPN} 100 \mathrm{~g}^{-1}$ in B. luctuosum and $94 \pm 6.56 \mathrm{MPN} 100 \mathrm{ml}^{-1}$ in seawater. When the animals were subjected to starvation these indicators were not detected in the homogenates. The SNK test performed on the significant $C o x T i$ interaction $(P<0.01)$, 
revealed that both total and faecal coliforms concentrations in polychaetes were significantly lower than in the surrounding environment over time $(P<0.01)$. Moreover, significant higher values occurred in unstarved B. luctuosum with respect to starved animals $(P<0.01)$, whereas no significant difference in seawater samples were detected. Regarding to faecal streptococci concentrations (Fig. 2b), the values recorded (about 11000 MPN $100 \mathrm{~g}^{-1}$ ) did not differ significantly between the unstarved and starved animals whilst a significant difference $(P<0.001)$ was observed between seawater and $B$. luctuosum with a density of 4 orders of magnitude higher in the worms both at $\mathrm{Ti}_{0}$ and $\mathrm{Ti}_{1}$ (Table 1).

\section{Discussion}

Results showed that B. luctuosum is able to accumulate all the six considered microbiological groups, thus reducing the microbial concentration in the surrounding environment. A similar microbiological accumulation capability has been demonstrated for the closely related species Sabella spallanzanii (Licciano et al., 2003; Stabili et al., 2006). The impact of grazing on bacteria may be crucial especially in coastal marine ecosystems where these sabellids could form dense populations and heterotrophic bacteria constitute a major biomass component. In such a case, the microbial loop can represent a biological force driving the energy flux and the functioning of ecosystems (Cho \& Azam, 1990; Fuhrman et al., 1989).

A selectivity in digesting was inferred from the results indicating:

- no significant differences between starved and unstarved B. luctuosum in the accumulation of the total culturable bacteria at $37^{\circ} \mathrm{C}$ and faecal streptococci. This means that these allochthonous bacteria do not find a suitable environment for their accumulation inside the worms, as observed in S. spallanzanii which was unable to 
digest faecal streptococci (Stabili et al., 2006). It has been demonstrated that Gram positive bacteria may be more resistant than Gram negative bacteria to digestion by marine invertebrates (Plante \& Shriver, 1998);

- a significant increase of total culturable heterotrophic bacteria as well as halophilic vibrios abundances was instead observed between starved worms and the unstarved ones. The same trend was recorded for vibrios. This could suggest that such bacteria, being typically marine, may be members of the worm microflora some of which could also be symbiotic, and that $B$. luctuosum could represent an ecological reservoir for survival and growth of these bacteria;

- finally, the study also revealed occurrence of total and faecal coliforms only in unstarved worms since in the starved ones these bacteria were completely absent. This finding indicates a lower efficiency of the worms, compared to seawater, to concentrate and accumulate microbial pollution indicators. To explain this, we hypothesize that in B. luctuosum the degradation processes prevailed over the filtering ones, thus masking the bacterial accumulation ability of this worm.

The selectivity of digestion of microorganisms has been studied in sponges and the bacterial adherence properties have been postulated to play a key role in the selective retention rate (Willenz \& van de Vyver, 1984; van de Vyver et al., 1985). Earlier studies on detritivorous polychaetes showed that some taxonomic groups of bacteria seem to fare well with gut throughput when compared to other groups (Plante \& Mayer, 1994). Moreover, studies on filter feeders have demonstrated that bacterial species differ in their resistance to digestion (Prieur et al., 1990). Our data were merely descriptive, therefore the mechanisms utilized by B. luctuosum to degrade bacteria were not analysed during this study and more studies are needed to establish the exact mechanisms involved in the bacterial digestion exerted by the investigated species. These mechanisms, as observed in 
other invertebrates, could include ciliary movements and mucus secretion which restrict microbial growth (Garland et al., 1982; Canicattì \& D'Ancona, 1990). Alternatively, the activity of antimicrobial compounds, especially lysozyme, could be hypothesized (Canicattì \& Roch, 1989; Stabili \& Canicattì, 1994; Stabili et al., 1996).

High microbial concentrations and the high accumulation efficiency inside the worms in comparison to the surrounding environment, especially regarding halophilic vibrios, suggest B. luctuosum as a useful bioindicator, particularly when low pollution levels of marine water pollution make environmental impact assessment procedures difficult. On the other hand, as suggested by Colwell (1984) and confirmed by other authors (Caruso et al., 1996; Cavallo \& Stabili, 2002; Zaccone et al., 2002), vibrios may represent an additional parameter to faecal coliforms in determining water quality. Moreover, monitoring for microorganisms other than coliforms is also recommended by various guidelines developed for estuarine waters (Neill, 2004), which, generally apply to bathing or recreational or shellfish harvesting areas. Specimens of B. luctuosum were, collected in a harbour area in the Gulf of Taranto subjected to anthropogenic pollution. Therefore the detection of elevated microbial pollution indicators lead us to consider this species as a suitable bioindicator, particularly because it is able to tolerate high levels of marine pollution and environmental instability.

According to the results about coliforms digestion, another applicative aspect of our research suggests the potential use of B. luctuosum as biofilter for sewage, such as urban waste or animal slurry, where faecal coliforms can provide information on the possible occurrence of enteric pathogens and the general level of the microbiological quality of water. The application of biotechnologies to the marine environment is a fairly "hot topic" addressed by the scientific community worldwide (Colwell, 1998, 2002) and in the recent years, several studies have been carried out to assess the potential of bioremediation for 
the recovery of impacted ecosystems (Bragg et al., 1994; Vezzulli et al., 2004). The increasing eutrophication of coastal aquatic ecosystems resulting from human activities (i.e. agriculture runoff, direct wastewater discharge, aquaculture and mariculture impacts, disturbance of natural water flows) (Mendez \& Comin, 2000), requires the recovery of the coastal polluted environments and the identification of bioremediator organisms. In the previous studies on S. spallanzanii (Licciano et al., 2003; Stabili et al., 2006), we suggested the use of this species in restoring water quality in aquaculture farms, based on its high capability to remove and digest vibrios from the surrounding environment. In comparison, our results demonstrate that B. luctuosum is more effective than $S$. spallanzanii in removing and digesting coliforms, supporting the possibility of its use as biofilter of domestic sewage.

The idea of employing polychaetes for applied purposes has been already suggested by several authors (Tenore et al., 1974; Ryther et al., 1975; Kurihara, 1983; Gambi et al., 1994; Giangrande et al., 2005), who considered only the application of some detritivorous polychaetes to reduce microbial and organic pollution in marine sediments. Therefore, the possibility of using filter feeder polychaetes as biofilters for the water column treatment, provides an innovative approach in the biological treatment of polluted sea water.

\section{Acknowledgements}

The authors are grateful to Dr. Antonio Terlizzi (Department of Biological and Environmental Science and Technology, University of Lecce) for his support in statistical analysis and helpful criticisms on an earlier version of this manuscript. 


\section{References}

APHA, AWWA, WEF (1998). US Standard Methods for the Examination of Water and Wastewater, $20^{\text {th }}$ ed., ISBN 0-87553-235-7. American Public Health Association.

Andral, B., Stanisiere, J.,Y., Sauzade, D., Damier, E., Thebault, H., Galgani, F. \& Boissery, P. (2004). Monitoring chemical contamination levels in the Mediterranean based on the use of mussel caging. Marine Pollution Bulletin 49, 704-712.

Ayres, P.A., Burton, H.W. \& Cullum, M.L. (1978). Sewage pollution and shellfish. In L. Davies (Ed.), Techniques for the study of mixed populations (pp. 51-62). New York: Academic Press.

Bak, R.P.M., Joenje, M., Lambrechts, D.Y.M. \& Nieuwland, G. (1998). Bacterial suspension feeding by coral reef benthic organisms. Marine Ecology Progress Series $175,285-288$.

Bianchi, C.N. (1983). Serpuloidei (Annelida, Polychaeta) delle lagune costiere laziali e campane. Annali del Museo Civico di Storia Naturale di Genova 84, 231-243.

Bocchetti, R., Fattorini, D. Gambi, M.C. \& Regoli, F. (2004). Trace metal concentrations and susceptibility to oxidative stress in the polychaete Sabella spallanzanii (Gmelin) (Sabellidae): potential role of antioxidants in revealing stressful environmental conditions in the Mediterranean. Archives of Environmental Contamination and Toxicology 46, 353-361.

Bolinches, J., Toranzo, A.E., Silva, A. \& Barja, J.L. (1986). Vibriosis as the main causative factor of heavy mortalities in the oyster culture industry in North-western Spain. Bulletin of the European Association of Fish Pathologists 6, 1-4.

Bonar, D.B. (1972). Feeding and tube construction in Chone mollis Bush (Polychaeta, Sabellidae). Journal of Experimental Marine Biology and Ecology 9, 1-18. 
Bostock, A.D. (1979). Hepatitis A infection associated with the consumption of mussel. Journal of Infectious Diseases 1, 171-177.

Bragg, J.R., Prince, R.C., Harner, E.J. \& Atlas, R.M. (1994). Effectiveness of bioremediation for the Exxon Valdez oil spill. Nature 368, 413-418.

Canicattì, C. \& D’Ancona, G. (1990). Biological protective substances in Marthasterias glacialis (Asteroidea) epidermal secretion. Journal of Zoology, London 222, 445-454.

Canicattì, C. \& Roch, P. (1989). Studies on Holothuria polii (Echinodermata) antibacterial proteins. I. Evidence for an activity of a coelomocyte lysozyme. Experientia 45, 756759.

Caruso, G., Zaccone, R. \& Crisafi, E. (1996). Distribution and numerical taxonomy of Vibrionaceae in the waters of the Straits of Messina. Microbiologica 19, 155-166.

Cavallo, A. \& Giangrande, A. (2002). Prove di sperimentazione ai fini dell'utilizzazione di Sabella spallanzanii (Polychaeta) come biorimediatore in acquicoltura. Biologia Marina Mediterranea 10(1), 438-440.

Cavallo, R.A. \& Stabili, L. (2002). Presence of vibrios in seawater and Mytilus galloprovincialis (Lam.) from the Mar Piccolo of Taranto (Ionian Sea). Water Research 36, 3719-3726.

Cho, B.C. \& Azam, F. (1990). Biogeochemical significance of bacterial biomass in the oceans' euphotic zone. Marine Ecology Progress Series 63, 253-259.

Clapin, G. (1996). The filtration rate, oxygen consumption and biomass of the introduced polychaete Sabella spallanzanii Gmelin within Cockburn Sound: can they control phytoplankton level and is it an efficient filter feeder? Honours Thesis, (pp. 90). Joondalup, Western Australia: Edith Cowan University.

Cloern, J.E. (1982). Does the benthos control phytoplankton biomass in the South San Francisco estuary? Marine Ecology Progress Series 9, 191-202. 
Colwell, R.R. (1984). Vibrios in the environment. New York: Wiley.

Colwell, R.R. (1998). Environmental biotechnology: the biotechnology revolution comes down to earth! Current Opinion in Biotechnology 9, 245-246.

Colwell, R.R. (2002). Fulfilling the promise of biotechnology. Biotechnology Advances $20,215-228$.

Dales, R.P. (1957). Some quantitative aspects of feeding in sabellid and serpulid fan worms. Journal of Marine Biological Association of the United Kingdom 36, 309-316.

Fattorini, D., Notti, A., Halt, M.N., Gambi, M.C. \& Regoli, F. (2005). Levels and chemical speciation of arsenic in polychaetes: a review. Marine Ecology 26, 255-264.

Fitzsimons, G. (1965). Feeding and tube-building in Sabellastarte magnifica (Shaw) (Sabellidae: Polychaeta). Bulletin of Marine Science 15, 642-671.

Fuhrman, J.A., Sleeter, T.D., Carlson, C. \& Proctor, L.M. (1989). Dominance of bacterial biomass in the Sargasso Sea and its ecological implications. Marine Ecology Progress Series 57, 207-217.

Gambi, M.C., Castelli, A., Giangrande, A., Lanera, P., Prevedelli, D. \& Zunarelli Vandini, R. (1994). Polychaetes of commercial and applied interest in Italy: an overview. Mémoires du Muséum National d'Histoire Naturelle 162, 593-603.

Garland, C.D., Nash, G.V. \& Mc Mukin, T.A. (1982). Absence of surface associated microorganisms in adult oysters (Crassostrea gigas). Applied and Environmental Microbiology 44, 1205-1211.

Giangrande, A., Cavallo, A., Licciano, M., Mola, E., Pierri, C. \& Trianni, L. (2005). Utilization of the filter feeder Sabella spallanzanii as bioremediator in aquaculture. Aquaculture International 13, 129-136.

Gili, J.M. \& Coma, R. (1998). Benthic suspension feeders: their paramount role in littoral marine food webs. Trends in Ecology and Evolution 13(8), 316-321. 
Jørgensen, C.B. (1966). Biology of suspension feeding. Oxford: Pergamon Press, pp. 357.

Jørgensen, C.B. (1975). Comparative physiology of suspension feeding. Annual Review of Physiology 37, 57-79.

Jørgensen, C.B., Kiørboe, T., Møhlenberg, F. \& Riisgård, H.U. (1984). Ciliary and mucus-net filter feeding, with special reference to fluid mechanical characteristics. Marine Ecology Progress Series 15, 283-292.

Kimmerer, W.J., Gartside, E. \& Orsi, J.J. (1994). Predation by an introduced clam as the likely cause of substancial declines in zooplankton in San Francisco Bay. Marine Ecology Progress Series 113, 81-93.

Knight-Jones, P. \& Ergen, Z. (1991). Sabelliform polychaetes, mostly from Turkey's Aegean coast. Journal of Natural History 25, 837-858.

Kurihara, I. (1983). Study of domestic sewage waste treatment by the polychaetes Neanthes japonica and Perinereis nuntia on artificial tidal flat. Internationale Revue der Gesamten Hydrobiologie 68, 649-670.

Lewis, D. (1968). Feeding and tube-building in the Fabriciinae (Annelida, Polychaeta). Proceedings of the Linnean Society of London 179(1), 37-49.

Licciano, M., Giangrande, A. \& Gambi, M.C. (2002). Reproduction and simultaneous hermaphroditism in Branchiomma luctuosum (Polychaeta, Sabellidae) from the Mediterranean Sea. Invertebrate Biology 121(1), 55-65.

Licciano, M., Stabili, L., Cavallo, R.A. \& Giangrande, A. (2003). Prove di stabulazione per la valutazione della capacità di accumulo microbiologico con il sabellide filtratore Sabella spallanzanii (Annelida: Polychaeta). Biologia Marina Mediterranea 10(2), 1105-1107. 
Licciano, M., Stabili, L. \& Giangrande, A. (2005). Clearance rates of Sabella spallanzanii and Branchiomma luctuosum (Annelida: Polychaeta) on a pure culture of Vibrio alginolyticus. Water Research 39(18), 4375-4384.

Mendez, M. \& Comin, F.A. (2000). Spring and summer proliferation of floating macroalgae in a Mediterranean coastal lagoon (Tancada Lagoon) Ebro Delta, NE Spain. Estuarine Coastal and Shelf Science 51, 215-226.

Neill, M. (2004). Microbiological indices for total coliform and E. coli bacteria in estuarine waters. Marine Pollution Bulletin 49, 752-760.

Officer, C.B., Smayda, T.J. \& Mann, R. (1982). Benthic filter feeding: a natural eutrophication control. Marine Ecology Progress Series 9, 203-210.

Plante, C.J. \& Mayer, L.M. (1994). Distribution and efficiency of bacteriolysis in the gut of Arenicola marina and three additional deposit feeders. Marine Ecology Progress Series 109, 183-194.

Plante, C.J. \& Shriver, A. (1998). Differential lysis of sedimentary bacteria by Arenicola marina: examination of cell wall structure and exopolimeric capsules as correlates. Journal of Experimental Marine Biology and Ecology 229, 35-52.

Prieur, D., Mével, G., Nicolas, J.L., Plusquellec, A. \& Vigneulle, M. (1990). Interactions between bivalve molluscs and bacteria in the marine environment. Oceanography and Marine Biology: an Annual Review 28, 277-352.

Ribes, M., Coma, R. \& Gili, J.M. (1999). Natural diet and grazing rate of the temperate sponge Dysidea avara (Demospongiae, Dendroceratida) throughout an annual cycle. Marine Ecology Progress Series 176, 179-190.

Riisgård, H.U. \& Ivarsson, N.M. (1990). The crown-filament pump of the suspension feeding polychaete Sabella penicillus: filtration, effects of temperature, and energy cost. Marine Ecology Progress Series 62, 249-257. 
Riisgård, H.U. \& Larsen, P.S. (1995). Filter-feeding in marine macro-invertebrates: pump characteristics, modelling and energy cost. Biological Reviews of the Cambridge Philosophical Society (London) 70, 67-106.

Riisgård, H.U. \& Larsen, P.S. (2001a). Minireview: ciliary filter feeding and bio-fluid mechanics - present understanding and unsolved problems. Limnology Oceanography 46(4), 882-891.

Riisgård, H.U. \& Larsen, P.S. (2001b). Comparative ecophysiology of active zoobenthic filter-feeding, essence of current knowledge. Journal of Sea Research 44, 169-193.

Ryther, J.H., Goldman, J.C., Gifford, C.E., Huguenin, J.E., Wing, A.S., Clarner, P.J., Williams, L.D. \& Lapointe, B.E. (1975). Physical integrated waste-recycling-marine polyculture systems. Aquaculture 5, 163-177.

Shumway, S.E., Bogdanowicz, C. \& Dean, D. (1988). Oxygen consumption and feeding rates of the sabellid polychaete, Myxicola infundibulum (Renier). Comparative Biochemistry and Physiology 90A(3), 425-428.

Silverman, H., Achberger, E., Lynn, J.W. \& Dietz, T.H. (1995). Filtration and utilization of laboratory-cultured bacteria by Dreissena polymorpha, Corbicula fluminea, and Carunculina texasensis. Biological Bulletin 189, 308-319.

Silverman, H., Nichols, S.J., Cherry, J.S., Achberger, E., Lynn, J.W. \& Dietz, T.H. (1997). Clearance of laboratory-cultured bacteria by freshwater bivalves: differences between lentic and lotic unionids. Canadian Journal of Zoology 75, 1857-1866.

Stabili, L. \& Canicattì, C. (1994). Antibacterial activity of the seminal plasma of Paracentrotus lividus. Canadian Journal of Zoology 72, 1211-1216.

Stabili, L., Pagliara, P. \& Roch, P. (1996). Antibacterial activity in the coelomocytes of the sea urchin Paracentrotus lividus. Comparative Biochemistry and Physiology 113 B3, 639-644. 
Stabili, L., Licciano, M., Giangrande, A., Fanelli, G. \& Cavallo, R. A. (2006). Sabella spallanzanii filter-feeding on bacterial community: Ecological implications and applications. Marine Environmental Research 61(1), 74-92.

Tenore, K.R., Browne, M.G. \& Chesney, E. (1974). Polyspecies aquaculture systems: the detrital trophic level. Sears Foundation. Journal of Marine Research 32, 425-432.

Underwood, A.J. (1997). Experiments in ecology: their logical design and interpretation using analysis of variance. Cambridge: Cambridge University Press, pp. 504.

van de Vyver, G., Vray, B., Belaouane, S. \& Toussaint, D. (1985). Efficiency and selectivity of microorganism retention by Ephydatia fluviatilis. 3d. International Sponge Conference pp. 511-515.

Vezzulli, L., Pruzzo, C. \& Fabiano, M. (2004). Response of the bacterial community to in situ bioremediation of organic-rich sediments. Marine Pollution Bulletin 49, 740-751.

Wells, G.P. (1952). The respiratory significance of the crown in the polychaete worms Sabella and Myxicola. Proceedings of the Royal Society B: Biological Sciences 140, $70-82$.

Widdows, J. \& Donkin, P. (1992). Mussels and environmental contaminants: bioaccumulation and physiological aspects. In Gosling, E.M. (Ed.), The mussel Mytilus: ecology, physiology, genetics and culture, (pp. 383-424). Amsterdam: Elsevier Science Publ. Developments in Aquaculture and Fisheries Science, no. 25.

Widdows, J., Brinsley, M.D., Salkeld, P.N. \& Elliott, M. (1998). Use of annular flumes to determine the influence of current velocity and bivalves on material flux at the sediment-water interface. Estuaries 21, 552-559.

Widdows, J., Brinsley, M.D., Salkeld, P.N. \& Lucas, C.H. (2000). Influence of biota on spatial and temporal variation in sediment erodability and material flux on a tidal flat (Westerschelde, The Netherlands). Marine Ecology Progress Series 194: 23-37. 
Widdows, J., Blauw, A., Heip, C.H.R., Herman, P.M.J., Lucas, C.H., Middelburg, J.J., Schmidt, S., Brinsley, M.D., Twisk, F. \& Verbeek, H. (2004). Role of physical and biological processes in sediment dynamics of a tidal flat in Westerschelde Estuary, SW Netherlands. Marine Ecology Progress Series 274: 41-56.

Willenz, P. \& van de Vyver, G. (1984). Ultrastructural localization of lysomila digestion in the freshwater sponge Ephydatia fluviatilis. Journal of Ultrastructure Research 87, $13-22$.

Wood, P.C. (1957). Factors affecting the pollution and self purification of molluscan shellfish. Journal du Conseil International pour l'Exploration de la Mer 22, 202-208.

Wotton, R.S. (1994). Methods for capturing particles in benthic animals. In: Wotton, R.S. (Ed.), The biology of particles in aquatic systems (pp. 183-204). Lewis Publishers.

Yam, W.C., Chan, C.Y., Ho Bella, S.W., Tam, T.Y., Kueh, C. \& Lee, T. (1999). Abundance of clinical enteric bacterial pathogens in coastal waters and shellfish. Water Research 34(1), 51-56.

Zaccone, R., Caruso, G. \& Calì, C. (2002). Heterotrophic bacteria in the northern Adriatic Sea: seasonal changes and ectoenzyme profile. Marine Environmental Research 54, 119. 
Figure Captions

Figure 1. Mean abundance and relative standard deviations of bacterial densities in seawater and worm samples at $\mathrm{Ti}_{0}$ (unstarved) and $\mathrm{Ti}_{1}$ (starved): a) culturable heterotrophic bacteria at $22^{\circ} \mathrm{C}$; b) vibrios; c) total culturable bacteria at $37^{\circ} \mathrm{C}$. (y axes are logged)

Figure 2. Mean abundance and relative standard deviations of microbial pollution indicators in seawater and worm samples at $\mathrm{Ti}_{0}$ (unstarved) and $\mathrm{Ti}_{1}$ (starved): a) total and faecal coliforms; b) faecal streptococci. 

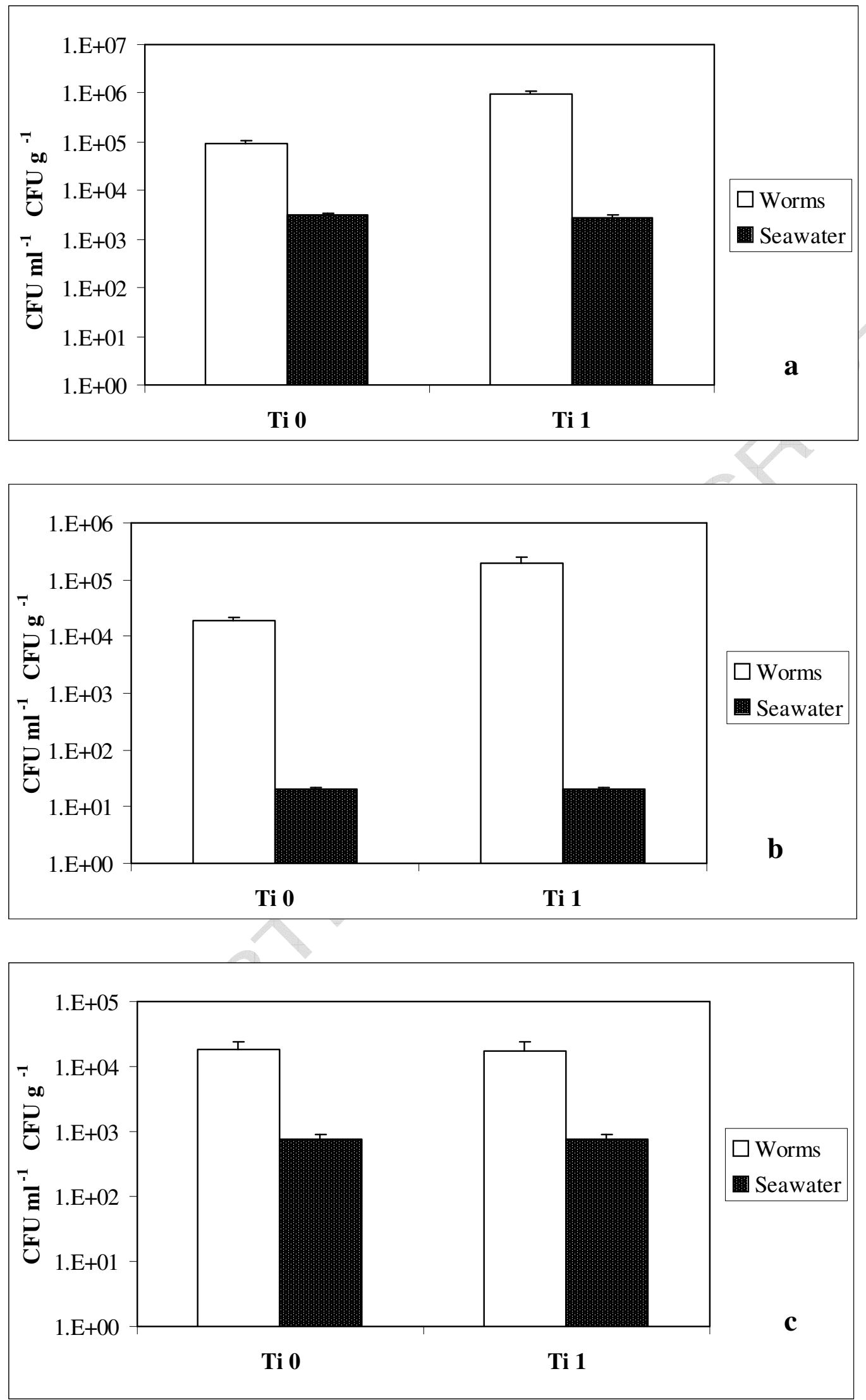

Fig. 1 


\section{ACCEPTED MANUSCRIPT}
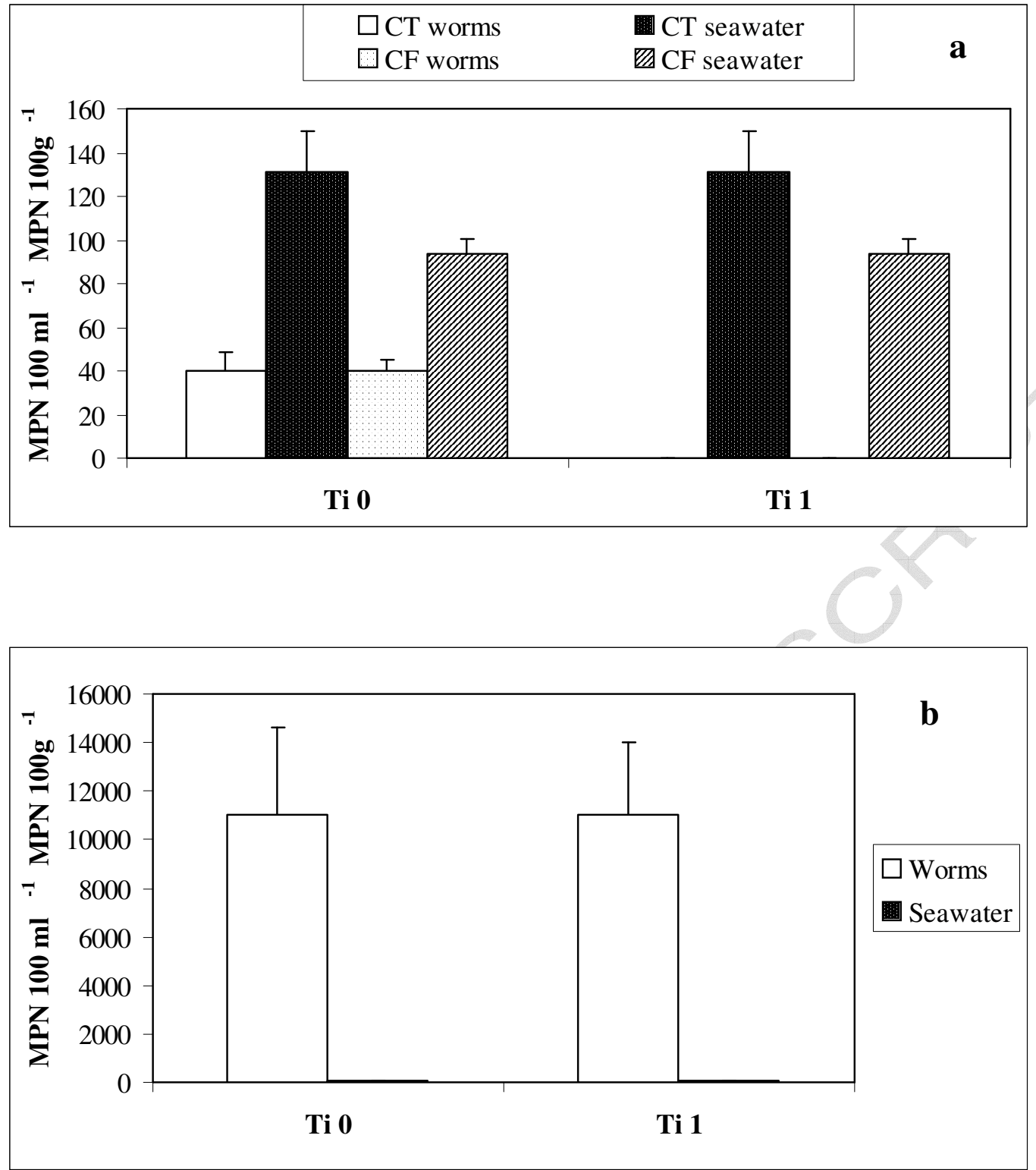

Fig. 2 


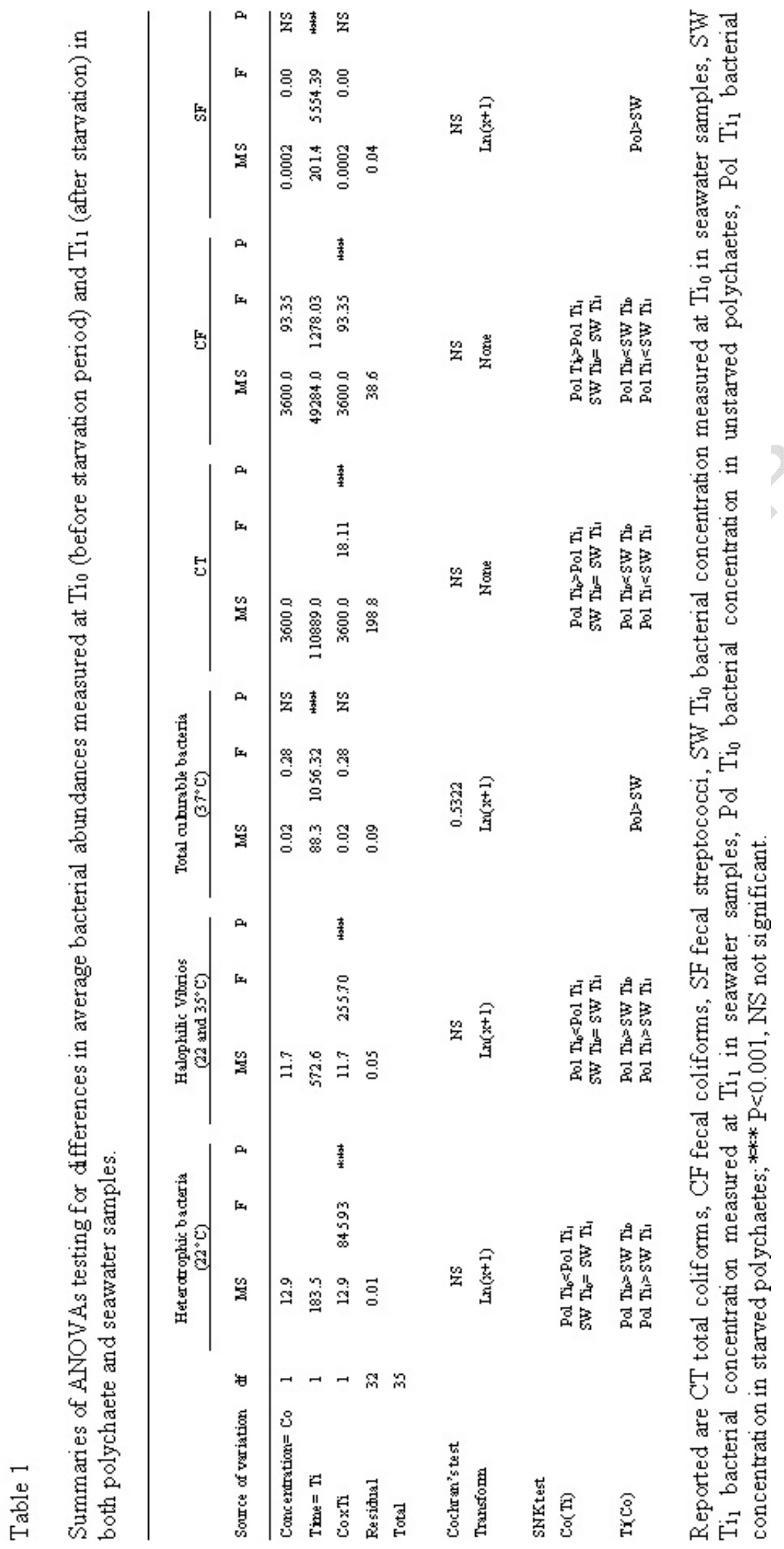

